\title{
SISTEM INFORMASI REKAM MEDIS PASIEN RAWAT JALAN DI UPTD PUSKESMAS KUNINGAN BERBASIS WEB
}

\author{
Tatang Saputra ${ }^{1}$, Erik Kurniadi ${ }^{2}$ \\ Fakultas Ilmu Komputer Universitas Kuningan \\ Kampus I : Jalan Cut Nyak Dhien 36A Kuningan
}

\begin{abstract}
Puskesmas adalah fasilitas kesehatan tingkat 1. Lebih dari $40 \%$ penduduk Indonesia memanfaatkan pelayanan kesehatan di Puskesmas. Hal tersebut memperlihatkan bahwa Puskesmas merupakan penyelenggara layanan kesehatan yang paling dekat dengan masyarakat. Pencatatan dokumen rekam medis pasien di Puskesmas Kuningan masih dilakukan secara manual. Pencarian data memiliki hambatan waktu. Hal ini terjadi karena sering ditemukan datadata yang sama. Pengelolaan rekam medis yang tidak efektif akan menjadi suatu masalah besar dalam pelayanan kesehatan di Puskesmas. Masalah tersebut harus dapat diatasi agar puskesmas tersebut memiliki data dan informasi yang baik. Salah satu cara mengatasi masalah tersebut adalah dengan membangun sistem informasi rekam medis terkomputerisasi. Rekam Medis merupakan kompilasi fakta tentang kondisi kesehatan dan penyakit seorang pasien. Rekam medis menjadi suatu hal yang sangat penting dalam penyelenggaran pelayanan kesehatan. Karena pentingnya suatu rekam medis, Penulis tertarik untuk melakukan penelitian dengan judul "Sistem Informasi Rekam Medis Pasien Rawat Jalan di UPTD Puskesmas Kuningan Berbasis Web”. Sistem informasi rekam medis ini diharapkan dapat membantu meningkatkan fungsi Puskesmas sebagai tempat pelayanan kesehatan. Dengan adanya sistem rekam medis, setiap riwayat pasien dapat tercatat dalam basis data sehingga memudahkan petugas dalam proses pencarian data rekam medis pasien pada saat diperlukan. Dengan adanya basis data, ketika pasien lupa membawa kartu berobat dapat dilakukan pencarian data pasien oleh petugas secara elektronik. Pembuatan laporan akan menjadi lebih mudah karena pengambilan data dilakukan melalui query sistem sehingga mempermudah proses dan meminimalisir kesalahan dalam pengelolaan data.
\end{abstract}

Kata Kunci : php, mysql, rekam medis, rawat jalan

Puskesmas is a level 1 health facility. More than $40 \%$ of Indonesia's population uses health services at the Puskesmas. It is interesting that the Puskesmas is the health care provider that is closest to the community. Recording medical records of patients at the Kuningan Health Center is still done manually. Data search has time constraints. This happens because the same data is often found. Ineffective management of medical records will become a major problem in health services at the Puskesmas. This problem must be overcome so that the puskesmas has good data and information. One way to overcome this problem is to build a computerized medical record information system. Medical Record is a compilation of facts about the health and illness of a patient. Medical Records become a very important thing in the delivery of health services. Because the importance of a medical record, the author is interested in conducting research with the title "Information Systems for Outpatient Medical Records in UPTD Puskesmas Kuningan Web-Based". The medical record information system is expected to help improve the function of the Puskesmas as a place of health care. With the existence of a medical record system, each patient visit can be taken in a database making it easier for officers in the process of finding medical record data when needed. With the database, the compilation of patients forgetting to bring a treatment card can be done by searching the patient's data by the electronic officer. Making a report will be easier because it retrieves data that is done through the request system so as to facilitate the process and minimize errors in data management.

Keywords: php, mysql, medical record, outpatient 


\section{Pendahuluan}

Puskesmas merupakan penyelenggara pelayanan kesehatan yang paling dekat dengan masyarakat menunjukkan lebih dari $40 \%$ penduduk Indonesia yang memanfaatkan pelayanan kesehatan di Puskesmas. Hal tersebut memperlihatkan bahwa Puskesmas sebagai penyelenggara layanan kesehatan untuk jenjang tingkat pertama atau paling dekat dengan masyarakat. .Puskesmas berupa pemeriksaan fisik dan pelayanan kesehatan langsung kepada masyarakat. Semua kegiatan ini kemudian didokumentasikan ke dalam buku operasioanal. Buku operasional pasien akan berguna sebagai data pelayanan kesehatan masyarakat. Buku rekam medis pasien juga digunakan untuk pencatatan dan penyimpanan data pemeriksaan pasien di seluruh unit pelayanan kesehatan dalam Puskesmas. Pencatatan dokumentasi atau rekam medis pasien di Puskesmas Kuningan masih dilakukan secara manual. Sehingga pada saat petugas mencari data seorang pasien akan merasa kesulitan, hal ini dikarenakan sering ditemukannya data-data yang sama. Mengingat kegunaan rekam medis itu sangat penting,dan menjadi suatu masalah yang dapat berpengaruh dalam pelayanan kesehatan di Puskesmas tersebut, Masalah tersebut dapat diatasi apabila dalam puskesmas tersebut memiliki sistem informasi rekam medis yang baik dan sudah terkomputerisasi. Rekam Medis juga merupakan kompilasi fakta tentang kondisi kesehatan dan penyakit seorang pasien yang meliputi data terdokumentasi tentang keadaan sakit sekarang dan waktu lampau serta pengobatan yang telah dan akan dilakukan oleh tenaga kesehatan secara tertulis. Dengan demikian terdapat beberapa masalah yang timbul (1).
Riwayat penyakit pasien belum tercatat sehingga banyak data pasien yang tidak tercatat. (2). Pasien sering lupa membawa kartu berobat jalan sehingga mengakibatkan pencarian data pasien jadi terhambat. (3). Kesulitan dalam mengambil data untuk laporan bulanan dan tahunan.

\section{Teori Dasar}

\subsection{Definisi Sistem Informasi}

Menurut Tata Sutabri (2012) bahwa "Sistem informasi adalah suatu sistem di dalam suatu organisasi yang mempertemukan kebutuhan pengolahan transaksi harian yang mendukung fungsi operasi organisasi yang bersifat manajerial dengan kegiatan strategi dari suatu organisasi untuk dapat menyediakan laporan-laporan yang diperlukan oleh pihak luar tertentu".

\subsection{Rekam Medis}

Dalam peraturan menteri kesehatan No. 269/2008, rekam medis adalah berkas berisi caratan dan dokumen tentang pasien yang berisi identitas, pemeriksaan, pengobatan, tindakan medis lain pada sarana pelayanan kesehatan untuk rawat jalan, rawat inap baik dikelola pemerintah maupun swasta.

Rekam medis adalah siapa, apa, mengapa, dimana, harapan dan bagaimana pelayanan yang diperoleh seorang dirawat dan diobati.

1. dokumen dianalisis polanya dengan machine learning untuk mendapatkan pola struktur dokumen kemudian dilakukan komparasi menggunakan metoda persamaan garis

2. Mendeteksi kesesuaian laporan dapat juga dilakukan dengan cara menganalisis secara gabungan seluruh dokumen terhadap panduan untuk pola struktur yang terbentuk. 
Kemudian dianalisis menggunakan metoda persamaan garis.

\section{Metode Pengembangan Sistem}

\subsection{Analisis Sistem Yang Diusulkan}

Pada sistem yang diusulkan, melibatkan admin, pasien, dokter, loket, dan kepala puskesmas. Akan tetapi sudah menggunakan sistem khusus terkomputerisasi dengan basis data terpusat. Pendaftaran pasien baru tetap diproses oleh bagian loket. Data tersimpan di dalam tabel pasien. Setelah terdaftar dalam database maka pasien dapat melakukan pendaftaran dan data tersimpan dalam tabel pendaftaran. Dokter dapat menampilkan data pendaftaran di dalam layar. Data tersebut digunakan untuk memanggil pasien yang telah mendaftar untuk melakukan proses pemeriksaan. Pada proses pemeriksaan dokter menginput data diagnosis. Semua data yang ada akan digunakan untuk pembuatan laporan. Sistem yang diusulkan dapat dilihat pada gambar berikut ini.

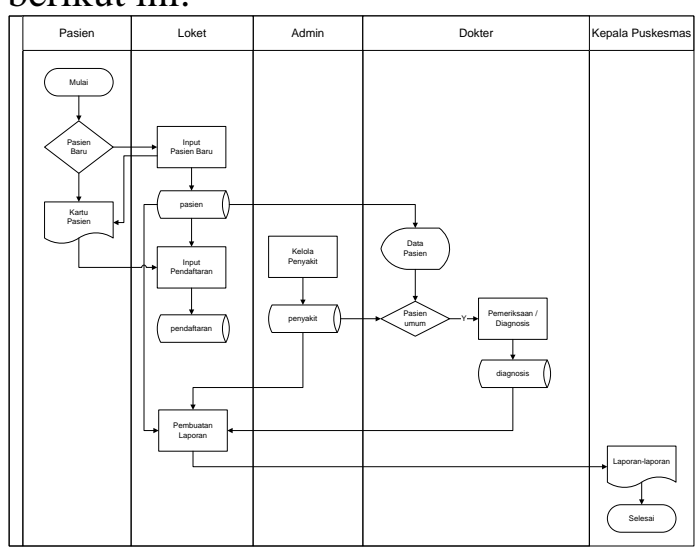

Gambar 1 Flowmap Sistem Yang Diusulkan

\section{Diagram Konteks}

Diagram konteks Distro Aspro dapat dilihat pada gambar 3 berikut ini.

\section{ERD}

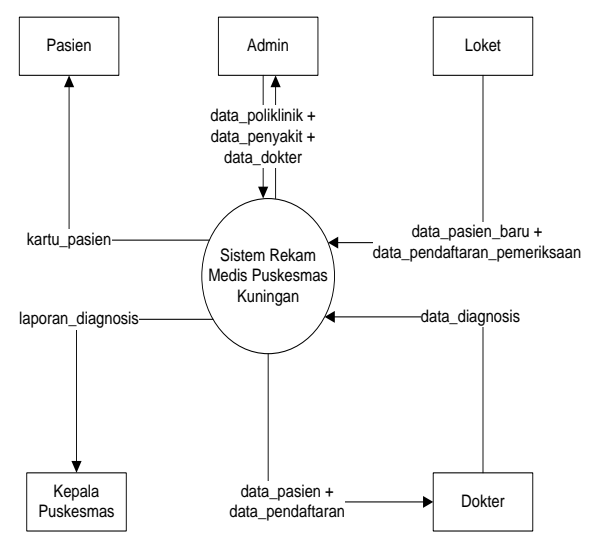

Gambar 2 Diagram Konteks

Entity Relationsip Diagram (ERD) adalah penggambaran hubungan diantara beberapa objek. ERD yang telah dirancang dapat dilihat pada gambar 3 berikut ini.

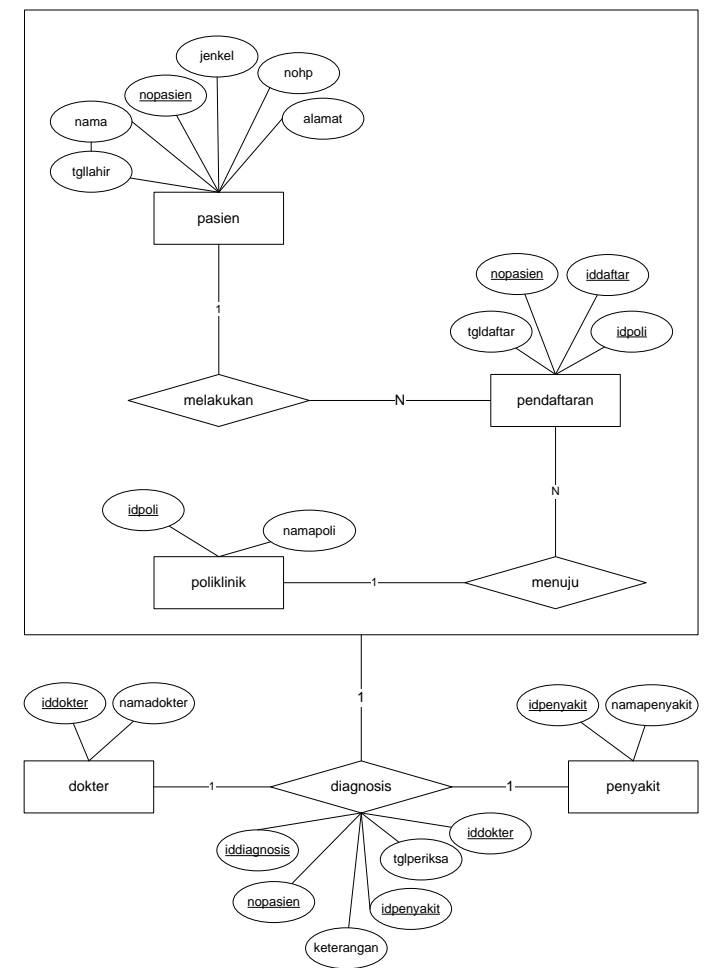

Gambar 3 Entity Relationship Diagram

\subsection{Hasil dan Pembahasan}

Sistem yang telah dibangun dicoba diimplemantasikan oleh penulis. Uji coba implemtasi dilakukan secara lokal dengan menggunakan web server apache dan database server mysql. Secara default sistem akan menampilkan 
halaman utama seperti yang terlihat pada gambar 4 dibawah ini.

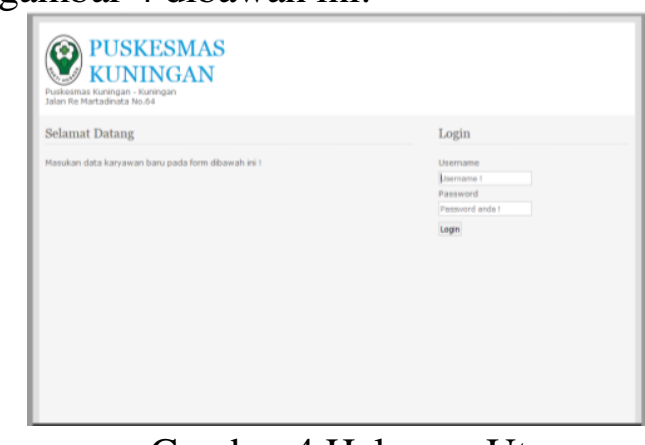

Gambar 4 Halaman Utama

\subsection{Penutup}

\section{Kesimpulan}

Berdasarkan hasil analisis, perancangan dan implementasi yang telah penulis lakukan, penulis mengambil kesimpulan-kesimpulan sebagai berikut

1. Dengan adanya sistem rekam medis, setiap riwayat pasien dapat tercatat dalam basis data sehingga memudahkan petugas dalam proses pencarian data rekam medis pasien pada saat diperlukan.

2. Dengan adanya basis data, ketika pasien lupa membawa kartu berobat dapat dilakukan pencarian data pasien oleh petugas.

3. Pembuatan laporan akan menjadi lebih mudah karena pengambilan data dilakukan melalui query sistem sehingga mempermudah proses dan meminimalisir kesalahan dalam pengelolaan data.

\section{Saran}

Dari hasil analisis, perancangan, implementasi dan kesimpulankesimpulan di atas, penulis mempunyai beberapa saran. Saran-saran penulis adalah sebagai berikut :

1. Dalam pengembangan selanjutnya, sistem ini dapat dilengkapi fitur rekam medis untuk pasien rawat inap.
2. Sebagai fasilitas kesehatan tingkat 1, sistem ini harus dapat mengakomodir perujukan pasien ke fasilitas kesehatan tingkat selanjutnya.

3. Penambahan fitur lain seperti pendaftaran pasien secara online / mobile, penyajian grafik laporan dan lain sebagainya.

\section{Daftar Pustaka}

Alfata, Hanif. (2009). Analisis dan Perancangan Sistem Informasi untuk Keunggulan Bersaingan Perusahaan dan Organisasi Modern. Yogyakarta: Andi Offset

Arief, M. Rudiyanto. (2011). Pemrograman Web Dinamis Menggunakan PHP dan MySQL. Yogyakarta : Andi.

Departemen Kesehatan Republik Indonesia. (2009). Undangundang Nomor 36 Tentang Kesehatan. [online]. Tersedia: http://www.depkes.go.id/resourc es/download/general/UU\%20No mor\%2036\%20Tahun2\%20009 $\% 20$ tentang\%20Kesehatan.pdf

Endah Setyorahayu, Berliana Kusuma Riasti. Pembangunan Sistem Informasi Pengolahan Data Pasien Rawat Inap Puskesmas Wonokarto. IJCSS - Indonesian Jurnal on Computer Science Speed - FTI UNSA ijcss.unsa.ac.id ISSN : 1979UNSA - ijcss.unsa.ac.id ISSN : 1979-9330 (Print) - 2088-0154 (Online) -2088-0162 (CDROM)

Jogiyanto HM. (2005). Analisis dan Desain Sistem Informasi Pendekatan Terstruktur Teori 
JURNAL NUANSA INFORMATIKA

Volume 13 Nomor 2, Juli 2019
p-ISSN : 1858-3911, e-ISSN : 2614-5405

https://journal.uniku.ac.id/index.php/ilkom

dan Praktek Aplikasi Bisnis.

Yogyakarta: Andi.

Ladjamudin, Al-Bahra Bin. (2013).

Analisis dan Desain Sistem

Informasi. Yogyakarta: Graha Ilmu.

Sutabri, Tata. (2004). Analisis Sistem Informasi.Yogyakarta: Andi Offset.

Sutabri,Tata. (2005). Sistem Informasi Manajemen. Yogyakarta: Andi OffSet.

Sutedjo, B. (2002). Perencanaan dan Pembangunan Sistem Informasi. Yogyakarta: Andi Offset

Wahana Komputer. (2005). Membuat aplikasi profesional dengan JAVA. Jakarta: PT Elex Media Komputindo. 